\title{
Traditional Tribal Conflicts in Darfur Reasons and Seasons
}

\author{
Dr. Anwar Yousif Atta Al-Mannan, \\ (PhD of Social Sciences), Sudanese Studies Centre, College of International Studies, \\ Yangzhou University, P.R.C. \\ Faculty of Management Sciences and Economics, Al-Butana University, Rufaa, Sudan.
}

\begin{abstract}
This research paper focused on the traditional tribal conflicts in Darfur, especially in the period following the independence of Sudan in 1956, which was dated from (1965-2002) in terms of their causes, and the role of conflict over scarce and diminishing resources in the friction between pastoralists and farmers, as well. The paper explained the most important areas in which conflicts are always took place, and why. The researcher explained the reasons for the development of these conflicts and the parties and elements that pitting them and cause them to expand. The paper addressed the roles played by the government, traditional civil administration and the neighboring tribes in mediating between the conflicting tribes. The paper also dealt with the local means taken from local heritage and custom, and the experience of this to resolve conflicts in Darfur and their effectiveness in tribal reconciliation, coupled with the most important tools acceptable to stabilize reconciliation, and ensure acceptance and non-reversal.The researcher conducted a questionnaire containing 400, (360 sound research samples), randomly selected from the geographical field of research, included different ages, gender, educational levels and professions, who were directly involved in or witnessed the conflicts. The researcher used the SWOT Analysis model, as the most suitable method of analysis in this type of research papers and through its findings from the analysis has been proposed a general framework for the life cycle of traditional tribal conflict in Darfur.
\end{abstract}

Keywords: Intellectuals, Politicians, Traditional civil administration, Government institutions, Unlicensed light weapons.

DOI: $10.7176 / \mathrm{JEP} / 10-32-11$

Publication date: November $30^{\text {th }} 2019$

\section{Introduction}

Darfur is Sudan's third largest region, covering the western part. Its total area is $570.888 \mathrm{~km} 2$ (140.000 sq. mi), which is equivalent to $20 \%$ of Sudan's area.

It lies between latitudes 10-16 north, longitudes 22-27.30 degrees east, and the temperature ranges between 3045 in summer and zero and 20 degrees in winter. ${ }^{(1)}$

Darfur is the second most populous in Sudan, with a population of 6.975 .000 , or $19.3 \%$ of Sudan's population. ${ }^{(2)}$

Although there are a significant number of people, outside the census area, as they are pastoral tribes, moving in pastoral paths and summer resorts, and therefore are difficult to control and follow-up.

There are a number of volcanic mountains in Darfur, the largest mountain range once, and Darfur has a number of seasonal rivers, the most important of which is the Arabian Sea in the Habbaniyah region, which flows into Bahr el Ghazal, which feeds Bahr alJabal at Nu Lake.

There are a number of permanent springs in Darfur. Ain Farah is located in Al Tanjar and Al Nakhilah Oasis, located in the west of the Western Desert.

There are also large valleys that pass through Darfur. In the north we find Wadi Hor, Wadi Al-Majjar and Wadi Azum, which comes out of Jebel Marra, the Great Azum Valley, Nyala Valley (Berley) and the Bulbul Valley, which lies to west of Nyala.

Rural people constitute the majority of the population of Darfur and constitute about $75 \%$ compared to $19.7 \%$ in urban areas and $5.25 \%$ in pastoral nomadic tribes. ${ }^{(3)}$

Large groups of Negro, Arab and Hamitic tribes have lived in Darfur since ancient times, and have intermarried which produced the present population. ${ }^{(4)}$

- Zaghawa centered on Wadi Tina and Wadi Hor and have a neighborhood with Mahriya.

- Mahriya centered on the mountains of Abu Qaran, Kabanga and Kutum.

- Masalit is bordered by Zaghawa from the north and Fur from the south and Mehri from the east.

- Rizeigat extends their area up to the Arabian Sea and bordering them from the east and east of the West

1. Resources and Environment in Darfur, State Ministry of Agriculture and Livestock Publications, Pasture Department, Nyala, South Darfur State, 2006.

2. Population Census 2008, Sudan States, Central Bureau of Statistics, Khartoum, Sudan, 2008.

3. 2008 Census, Urban and Rural Population Distribution in South Darfur, Central Bureau of Statistics, Khartoum, Sudan, 2008

4. Salem Ababneh, Sudan's Darfur Tribes (Western Sudan), first edition, Al-Dauzen Printing Press, Jordan, 1995. 
Habbaniyah and is bordered to the north by the Barqad, Dajo, Zaghawa and their main cities Abu Jabra and Al Daein.

- The Fur are stationed in the Jebel Marra area with their capital Nyala and neighboring all tribes.

- Habbaniyah are located in the Bram area.

- Al-Ma'alia in the Adela area.

- Al-Qayyimir neighbors their Masalit and Zaghawa.

- Fallatah is based in Toulouse.

- Ta'aisha is bounded by Fur and Masalit from the north and extends their area to the sea of Ada.

- Salamat bordering the Ta'aisha tribe and are stationed in the Raheid Al-Birdy area.

- Abu Darq are stationed in Bram and Wad Hijam, the neighbors of Habbaniyah.

- Awlad Kayed and Awlad Mansour tribe in the Malam area and to the west of the Fur tribe

According to this brief description of the geography of Darfur, it was found that most of the tribal groups, mostly made up of pastoralists and farmers, meet almost twice a year. In the autumn, pastoralists meet farmers in the eastern part of the central region of Darfur, and in the dry summer, most pastoralists spend this period around valleys and groundwater wells, which are inhabited by settled populations, and are mostly farmers, especially in the west, central and south of Darfur.

North Darfur has a majority of pastoralists who spend the winter until February in the desert and semidesert climate, after which they begin to move with their livestock across the state. The cities of Darfur contain a variety of all tribes, and have keep contact with their relatives in pasture and farming areas. ${ }^{(1)}$

All tribal warfare events are among the tribes that share tangential lines, that is, common borders, pasture contact areas, or tribal friction in the paths taken by pastoralists on their journeys back and forth, often in the autumn in South Darfur., And in winter in areas of North Darfur ${ }^{(2)}$

\section{Literature Review:}

There are several working papers on traditional tribal disputes, all presented a wealthy article with regard to the statistics of the peace conferences held, and attempted to identify the shortcomings and positives of traditional dispute resolution mechanisms. Good analyzes were provided with regard to the reasons for the failure of traditional dispute resolution mechanisms, including the peace conferences.

Causes of Tribal Conflicts in Darfur, Paper Presented at the Workshop: Insights on Tribal Conflicts in Sudan, written by General Tayeb Abdul Rahman Mukhtar, former Governor of Darfur under President Nimeiri, in which he expressed his personal vision through his experience in power and his participation in many tribal reconciliation conferences in the 1970s. In the last century, he mentioned attempts at conflict resolution, and conference recommendations, which were based on local tools taken from traditional heritage, such as Judea, Rawakeeb, Deyat and their role in stability. ${ }^{(3)}$

Al-Tijani Mustafa's book: "The Tribal Conflict in Darfur Causes, Repercussions, and Treatment is an important study in its profound analysis of the causes of conflicts, despite that, the remedies he proposed did not depart from the traditional heritage and were not so radical ${ }^{(4)}$

Historians of the tribal conflict in Darfur assert that the first conflicts were in 1932, between the Ziyadiya and Medub tribes against the Kababish and Kwahala tribes in North Darfur (El Fasher) and were repeated in 1957, 1982 and 1997. The conflicts were caused by competition over water resources and grazing. However, the real conflict began in 1983 between pastoral tribes and farmers, due to competition for scarce resources and arable land. $\left({ }^{5)}\right.$

A paper by Fouad Ali, Tribal Conflicts: Causes and Mechanisms for Resolving, presented at the Conflict Resolution Workshop, Africa International University, and this paper also did not go beyond the context of the causes, and the regular treatments that are repeated in all research papers. ${ }^{(6)}$

The Darfur Crisis: Causes and Future, an important article written by academic researcher, Dr. Haidar Ibrahim Ali, in which he discussed the reasons outside the context of competition for resources between farmers and pastoralists, namely the competition for power in the region, as a result of local governance reformation, brought by The Nimeiri regime (1985-69). Dr. Haidar also mentioned the government's abolition of the traditional local governance system in order to develop the local government system, but the government could

5. A. Yusuf, the Mechanism of Tribal Armed Conflict in South Darfur, Sudanese Writings Journal, Issue 31, March 2005.

6. Aoun Al-Sharif Gasim, Encyclopedia of Tribes and Genealogy in Sudan - First Edition, Afrography Press for Printing and Packaging, Khartoum, 1996.

7. Al-Tayeb Abdul Rahman Mukhtar, Causes of Tribal Conflicts in Darfur, paper presented in workshop entitled: Visions on Tribal Conflicts in Sudan, Al-Sharqa Hall, Khartoum University, 1998.

8. Al-Tijani Mustafa, the Tribal Conflict in Darfur, its Causes, Implications, and Treatment; A Study in Sociology and Applied Anthropology; Issued by Sudan Printing Press Co., Ltd., Khartoum, 1999.

9. http://raseef22.com/article/1073721/june29,2017/Islam Abdulrahman/ the causes and consequences of the tribal conflict in Darfur

10. Fouad Ali, Tribal Conflicts: Causes and Mechanisms for Resolving, Research Paper, Conflict Resolution Workshop, Africa International University, Khartoum, November 1996. 
not impose the new system, which found resistance from the local population who refused to cooperate with the new administrators. The new management organizations could not solve the problems but, added new complexities. The government attempted to draw new boundaries for tribal presence, which means that displaced migrants become tribal rights holders, at the expense of host tribes. These conditions have led to war, especially as the region has been brought in by large quantities of weapons as a result of the Chadian wars. Consequently, all types of weapons in the Darfur region are easier to obtain. ${ }^{(1)}$

The study of Dr. Osama Ali Zain Al-Abidin: "Darfur, the historical background of the crisis and the reasons for its development", aimed to show that, the phenomenon of tribal conflict in Darfur is very old, and began with the second Sultanate of Darfur in 1605, which was founded by Sultan Suleiman Selunga, and originally based on the tribal nervousness of the branch of the Kira tribe, Which extended its authority over most tribes, especially in peripheral areas.

The writer also pointed out that, the wars in Darfur have continued since the Turkish rule, during the period of Salatin Pasha, and then during the Mahdist revolution.

The writer focused on historical events and although he made efforts to clarify the characteristics of social backwardness and lack of development, he did not provide any direct remedies to the cause of conflicts. ${ }^{(2)}$

Tim Neiblok, in his book, The Conflict of Power and Wealth in Sudan from Independence to the revolutionary uprising 1985, decided that the states of Darfur, despite its population density and large geographical area, and the abundance and diversity of its promising natural resources are still considered one of the most underdeveloped areas of Sudan. There were no development projects in the post-independence period, which deprived them of a fair share in the division of wealth. Also, during colonial rule, areas in central Sudan experienced some developmental progress, while the peripheral regions did not

Neiblok also followed the same descriptive approach to the situation in Darfur, and did not provide perceptions helping to get out of the vicious circle of underdevelopment ${ }^{(3)}$

\section{Historical background about tribal conflicts in Darfur:}

The table below gives references to some of the traditional tribal conflicts in Darfur, that have taken place in the period (1965 - 2002), determining their temporal and spatial scope, causes, parties to the conflict, findings and recommendations of peace commissions and tools of reconciliation.

\begin{tabular}{|c|c|c|c|c|c|}
\hline $\begin{array}{l}\text { The } \\
\text { Date }\end{array}$ & $\begin{array}{l}\text { Tribes of } \\
\text { Conflicts }\end{array}$ & $\begin{array}{l}\text { Conflict } \\
\text { zone }\end{array}$ & $\begin{array}{l}\text { The causes of } \\
\text { the conflict }\end{array}$ & $\begin{array}{l}\text { The losses resulting } \\
\text { from the conflict }\end{array}$ & $\begin{array}{llll}\begin{array}{l}\text { Processes made solve the } \\
\text { problem }\end{array} & & \\
\end{array}$ \\
\hline 1965 & $\begin{array}{l}\text { Zaghawa } \\
- \text { Ababa }\end{array}$ & $\begin{array}{l}\text { North } \\
\text { Darfur }\end{array}$ & $\begin{array}{l}\text { Assault, theft } \\
\text { and mutual } \\
\text { accusations }\end{array}$ & $\begin{array}{l}\text { A large number of dead } \\
\text { and wounded. Looting } \\
\text { cattle }\end{array}$ & $\begin{array}{l}\text { 1. The intervention of } \\
\text { traditional civil } \\
\text { administration and } \\
\text { neighborhood tribes. } \\
\text { 2. Tribal reconciliation and } \\
\text { financial compensation }\end{array}$ \\
\hline 1974 & $\begin{array}{l}\text { The tribe } \\
\text { of Bani } \\
\text { Halba - } \\
\text { Maharia }\end{array}$ & $\begin{array}{l}\text { The } \\
\text { village of } \\
\text { Abu } \\
\text { Karnka }\end{array}$ & $\begin{array}{l}\text { Competition } \\
\text { in the } \\
\text { electoral } \\
\text { district of } \\
\text { parliament }\end{array}$ & $\begin{array}{l}\text { 6. } \begin{array}{l}\text { A large } \\
\text { number of } \\
\text { dead and } \\
\text { wounded } \\
\text { between the } \\
\text { two sides. }\end{array} \\
\text { 7. } \begin{array}{l}\text { Robbery, } \\
\text { looting and } \\
\text { vandalism. } \\
\text { Incitement to } \\
\text { revenge }\end{array}\end{array}$ & $\begin{array}{l}\text { 1. Stop fighting and } \\
\text { disconnect the two } \\
\text { parties. } \\
\text { 2. Returned cattle. } \\
\text { 3. Payment of financial } \\
\text { compensation between } \\
\text { the parties. } \\
\text { 4. The obligation to invoke } \\
\text { the law and the presence } \\
\text { of regular forces. } \\
\text { 5. Peace and amnesty. }\end{array}$ \\
\hline
\end{tabular}

11. Haider Ibrahim Ali, Darfur Crisis: Causes and Future, Article, al-bait Al-Arabi Forum Conference, al-bait Al-Arabi Magazine, Madrid, September 2007

12. Osama Ali Zein El Abidine, Darfur: The Historical Background of the Crisis and the Reasons for Its Development, Research Paper, Center for Middle East and Africa Studies, Khartoum, November 2003

13. Tim Neiblok, The Conflict of Power and Wealth in Sudan, From Independence to the Uprising, Translated by Al-Fatih Al-Tijani, Muhammad Ali, Without Publishing House, 1990. 


\begin{tabular}{|c|c|c|c|c|c|}
\hline $\begin{array}{l}\text { The } \\
\text { Date }\end{array}$ & $\begin{array}{l}\text { Tribes of } \\
\text { Conflicts }\end{array}$ & $\begin{array}{l}\text { Conflict } \\
\text { zone }\end{array}$ & $\begin{array}{l}\text { The causes of } \\
\text { the conflict }\end{array}$ & $\begin{array}{l}\text { The losses resulting } \\
\text { from the conflict }\end{array}$ & $\begin{array}{l}\text { Processes made solve the } \\
\text { problem }\end{array}$ \\
\hline 1974 & $\begin{array}{l}\text { The tribe } \\
\text { of Bani } \\
\text { Halba - } \\
\text { Maharia }\end{array}$ & $\begin{array}{l}\text { Kaya } \\
\text { Valley }\end{array}$ & $\begin{array}{l}\text { The } \\
\text { encroachment } \\
\text { on the gum } \\
\text { arabic farms } \\
\text { of the tribe of } \\
\text { Bani Halba }\end{array}$ & $\begin{array}{l}\text { 4. The death of } \\
\text { two and } \\
\text { number of } \\
\text { wounds } \\
\text { 5. The loss of } \\
\text { many beasts. } \\
\text { 6. Expand and } \\
\text { conflict and } \\
\text { extend to other } \\
\text { areas }\end{array}$ & $\begin{array}{l}\text { 1. Intervention by the } \\
\text { traditional civil } \\
\text { administration and calm } \\
\text { the situation. } \\
\text { 2. Payment of blood } \\
\text { money from both } \\
\text { parties. } \\
\text { 3. Peace and amnesty. }\end{array}$ \\
\hline 1983 & $\begin{array}{l}\text { Flata }- \\
\text { Gimir }\end{array}$ & $\begin{array}{l}\text { West of } \\
\text { the } \\
\text { valley of } \\
\text { Bulbul }\end{array}$ & $\begin{array}{l}\text { Conflict over } \\
\text { land, tribal } \\
\text { lands and } \\
\text { boundaries of } \\
\text { local councils } \\
\text { ( Himeidaya) }\end{array}$ & $\begin{array}{ll}\text { 1. } & \text { Dead and } \\
\text { wounded } \\
\text { 2. } & \text { Great tension }\end{array}$ & $\begin{array}{l}\text { The government intervened } \\
\text { strongly and solved the problem } \\
\text { within the framework of the rural } \\
\text { councils. }\end{array}$ \\
\hline 1986 & $\begin{array}{l}\text { Dinka- } \\
\text { Rizeigat }\end{array}$ & Abyei & $\begin{array}{l}\text { Stealing and } \\
\text { killing }\end{array}$ & $\begin{array}{lll}\text { 1. } & \text { Murder and } \\
\text { loot } & \\
\text { 2. } & \text { Burn } \\
\text { 3. } & \begin{array}{l}\text { Robbery and } \\
\text { rape }\end{array} \\
\end{array}$ & $\begin{array}{l}\text { The intervention of traditional } \\
\text { civil administration and } \\
\text { neighborhood tribes }\end{array}$ \\
\hline 1991 & $\begin{array}{l}\text { Rizeigat- } \\
\text { Maalia }\end{array}$ & $\begin{array}{l}\text { Tabbat } \\
\text { Village }\end{array}$ & $\begin{array}{l}\text { Defending } \\
\text { the honor of } \\
\text { women The } \\
\text { dignity and } \\
\text { reputation of } \\
\text { the tribe }\end{array}$ & $\begin{array}{l}\text { 1. large number } \\
\text { of dead and } \\
\text { wounded } \\
\text { 2. Robbery, } \\
\text { looting and } \\
\text { rape } \\
\text { 3. Incitement to } \\
\text { revenge }\end{array}$ & $\begin{array}{l}\text { 1. Stop the fighting and } \\
\text { separate the parties. } \\
\text { 2. Religious teachings and } \\
\text { dignity. } \\
\text { 3. Financial compensation. } \\
\text { 4. Traditional civil } \\
\text { administration has } \\
\text { played a major role in } \\
\text { the solution. }\end{array}$ \\
\hline 1994 & $\begin{array}{l}\text { Zaghawa } \\
\text { - Abala }\end{array}$ & $\begin{array}{l}\text { North } \\
\text { Darfur }\end{array}$ & $\begin{array}{l}\text { Tribal } \\
\text { revenge }\end{array}$ & $\begin{array}{l}\text { A large number of dead } \\
\text { and wounded }\end{array}$ & $\begin{array}{l}\text { The intervention of the } \\
\text { government and traditional civil } \\
\text { administration, containment of } \\
\text { the problem and bringing } \\
\text { perpetrators to justice }\end{array}$ \\
\hline 1997 & $\begin{array}{l}\text { Rizeigat- } \\
\text { Zaghawa }\end{array}$ & $\begin{array}{l}\text { Mturt } \\
\text { Village }\end{array}$ & $\begin{array}{l}\text { National } \\
\text { Council } \\
\text { elections }\end{array}$ & dead and wounded & $\begin{array}{l}\text { Government intervention, } \\
\text { traditional civil administration } \\
\text { and law enforcement }\end{array}$ \\
\hline 1998 & $\begin{array}{l}\text { Habbanieh } \\
- \\
\text { Aboudark }\end{array}$ & $\begin{array}{l}\text { The } \\
\text { village of } \\
\text { Korba }\end{array}$ & $\begin{array}{l}\text { The conflict } \\
\text { over the } \\
\text { leadership of } \\
\text { the tribe and } \\
\text { the (mayors) }\end{array}$ & $\begin{array}{l}\text { Dead, wounded and } \\
\text { ruined }\end{array}$ & $\begin{array}{l}\text { The government, neighborhood } \\
\text { tribes and traditional civil } \\
\text { administration are involved in } \\
\text { solving the problem }\end{array}$ \\
\hline 2001 & $\begin{array}{l}\text { Awlad } \\
\text { Qaed } \\
\text { Group - } \\
\text { Awlad } \\
\text { Mansour } \\
\text { Group }\end{array}$ & $\begin{array}{l}\text { Inside } \\
\text { the lands } \\
\text { of the } \\
\text { Mahariya } \\
\text { tribe }\end{array}$ & $\begin{array}{l}\text { Theft and } \\
\text { mutual } \\
\text { accusations } \\
\text { of assault by } \\
\text { both sides }\end{array}$ & $\begin{array}{l}\text { 1. Theft of } \\
\text { Beasts } \\
\text { 2. Mutual } \\
\begin{array}{l}\text { accusations of } \\
\text { aggression }\end{array}\end{array}$ & $\begin{array}{l}\text { Since the conflict was within the } \\
\text { tribe represented in its bellies, the } \\
\text { conflict was quickly contained by } \\
\text { tribal elders and traditional civil } \\
\text { administration and the } \\
\text { perpetrators were punished by } \\
\text { tribal elders. }\end{array}$ \\
\hline
\end{tabular}




\begin{tabular}{|l|l|l|l|l|l|}
\hline $\begin{array}{l}\text { The } \\
\text { Date }\end{array}$ & $\begin{array}{l}\text { Tribes of } \\
\text { Conflicts }\end{array}$ & $\begin{array}{l}\text { Conflict } \\
\text { zone }\end{array}$ & $\begin{array}{l}\text { The causes of } \\
\text { the conflict }\end{array}$ & $\begin{array}{l}\text { The losses resulting } \\
\text { from the conflict }\end{array}$ & $\begin{array}{l}\text { Processes made solve the } \\
\text { problem }\end{array}$ \\
\hline 2002 & $\begin{array}{l}\text { The Fur } \\
\text { tribe }-\end{array}$ & $\begin{array}{l}\text { South of } \\
\text { the city } \\
\text { Arabs Kass } \\
\text { in the } \\
\text { Jebel } \\
\text { Marra } \\
\text { area }\end{array}$ & $\begin{array}{l}\text { The Fur } \\
\text { Farms were } \\
\text { attacked by } \\
\text { the pastoral } \\
\text { tribes of } \\
\text { Abala }\end{array}$ & $\begin{array}{l}\text { A large number of dead } \\
\text { and wounded, burning } \\
\text { villages and looting }\end{array}$ & $\begin{array}{l}\text { The intervention of the } \\
\text { government, represented by the } \\
\text { police and the army to contain the } \\
\text { conflict, and a strong indicator of } \\
\text { the transformation of the conflict } \\
\text { to a different form than the norm } \\
\text { in tribal conflicts in Darfur, } \\
\text { entered a new pattern, the conflict } \\
\text { between Arabs and people of } \\
\text { african descent, for the first time } \\
\text { the history of conflicts in } \\
\text { in the } \\
\text { Darfur. }\end{array}$ \\
\hline
\end{tabular}

The table is designed by the researcher based on different sources. ${ }^{(1),(2),(3),(4),(5)}$

\section{Methodology and Analysis:}

In this section, a description of the methodology used in the implementation of this study, including a description of the study population, sample method, and statistical processing through which the data were analyzed and the results extracted.

\section{Study Population and Sample:}

The sample of the study was randomly selected from the study population, where the researcher distributed (400) questionnaire forms to the targeted, and (360) respondents, who returned the questionnaires after filling with all the required information, which is about $(90 \%)$ of the targeted.

In order to come up with as accurate results as possible, the researcher was keen on the diversity of the sample of the study in terms of including the following:

- Individuals of both sexes (male, female)

- Individuals of different age groups

- Individuals of different educational qualifications

- Individuals from different tribes

- Individuals of various professional positions.

- Individuals of different marital status (married, unmarried).

\section{Questionnaire and statistical analysis:}

In this section we will analyze the questionnaire and analyze the responses and opinions of the participants from the random samples that were interrogated and polled. As we mentioned, they were men of different age groups who participated directly in these conflicts or who were witnesses at the time of their occurrence.

\section{The analysis will cover the following scenes:}

- Traditional causes of conflict, the beginning of the conflict and its limbs.

- How were the reactions?

- What is the type of response when reporting to the police or traditional civil administration?

- What factors have fueled the conflict?

- How does the conflict stop?

- What are the preferred means of ending conflict and achieving reconciliation?

Traditional causes of conflict, the starting of the conflict and its limbs

\begin{tabular}{|l|l|l|l|}
\hline$\#$ & Traditional causes of conflict & \# of answers & Percentage \\
\hline 1 & A group of tribe attacking a group from another tribe & 210 & $58.33 \%$ \\
\hline 2 & A person from a tribe assaults a person from another tribe & 150 & $41.67 \%$ \\
\hline
\end{tabular}

$58.33 \%$ of respondents answered that the traditional reasons that lead to the beginning of the conflict are the

14. Sudan Strategic Report, Center for Strategic Studies, Khartoum, Sudan, 2002.

15. Report of the Agriculture Sector Committee: Investment Map, Ministry of Economy and Manpower, South Darfur State, 2003.

16. Juma Kinda, Marginalized Areas and the Political Future of Sudan, Sudanese Writings Journal, No. 3, Center for Sudanese Studies, Khartoum, 2005

17. Dr. Al - Tijani Mustafa Mohamed Saleh: Causes of Tribal Conflict in Sudan, paper presented at a seminar entitled (Visions on Tribal Conflicts in Sudan), Institute of African and Asian Studies, University of Khartoum, 1998.

18. M. Al - Sharif: Ownership of Land and Al - Hawakir in Darfur, Paper presented to the Peace building Workshop, Center for Western Sudan Studies, Nyala, 2005. 
infringement of a tribal group, on another tribal group, for various reasons, including the traditional tribal conflict over the natural resources of land and water, political rivalries, attempts at tribal administrative independence, and the defense of honor and sometimes For ethnic reasons or for looting and theft. While $41.67 \%$ of respondents said that the traditional causes of conflict are assaults on a person as a result of individual attacks that take the form of mass quickly, not far from the first form of the beginning of the conflict. On rare occasions, another tribe is concerned with the development of the conflict on its own agenda, sometimes also because of the negative interference of politicians and intellectuals, but still remains within the context of traditional tribal conflicts and competition.

In the next paragraph, we examine and clarify the dimensions of the moment when the conflict begins.

\section{The moment of the explosion of the conflict and its motives:}

In this study, as we mentioned, we focus on the moment when the conflict erupts. The cause, consequences, its indicators, Characteristics, traditions and the effects of weakness and underdevelopment of socio-economic mobility on it.

The majority of respondents were directly involved in tribal wars or stand as witnesses, all of whom confirmed that the moment of conflict eruption is always one of two scenes.

The first scene: an individual attack whose sides are from two different tribes, often adjacent and sharing natural resources, leading to the death of one of the parties. This brings us directly into the second scene, which is a sequel to the first scene where it turns into a conflict between two groups belonging to the same two tribes, motivated by vengeance, .

\section{The scene can be represented as follows:}

People often gather at the water distribution station to water the animals, compete for watering, and sometimes there are tribal provocations related to ethnic or tribal origin. Sometimes animals are prevented from water, friction occurs, and then recklessness, murder, and fuss ignite the problem. The event can take another form, one of which affects the cultivation of another, the animals are dealt with and the previous scenario is repeated.

\section{Feedback on abuse}

\begin{tabular}{|c|l|l|l|}
\hline$\#$ & Reaction & \# of answers & $\%$ \\
\hline 1 & Reporting to the police & 100 & 27.77 \\
\hline 2 & Inform the traditional civil administration & 70 & 19.44 \\
\hline 3 & Inform the police and at the same time respond similarly & 46 & 12.77 \\
\hline 4 & $\begin{array}{l}\text { Inform the police and the traditional civil administration and at the same time } \\
\text { respond similarly }\end{array}$ & 84 & 23.33 \\
\hline 5 & Reply similarly and wait & 55 & 15.27 \\
\hline 6 & Inform the traditional civil administration and at the same time respond similarly & 5 & 1.38 \\
\hline
\end{tabular}

From the previous table, it is clear that $27.77 \%$ of reactions to attacks are notified to the police as a normal measure, and in $23.33 \%$ of cases the police and the traditional civil administration are notified and respond similarly at the same time, and in $19.44 \%$ the traditional civil administration is notified to act to end the conflict, but $15.27 \%$ of the reactions are reciprocal in the sense of retaliation and awaiting the development of events, and in the fourth place with $12.77 \%$ of the reactions are notified to the police and respond similarly at the same time, and finally at a weak rate is to inform the traditional civil administration and respond similarly.

The above, indicates that, despite the domination of the tribe and tribal intolerance, the police and the law are in the mind of the citizen, and that it gives priority to the application of the law, and then come other forms of reactions.

Type of response when reporting to the police and traditional civil administration

\begin{tabular}{|l|l|l|l|}
\hline$\#$ & Type of response & \# of Answers & $\%$ \\
\hline & Slow or weak & 198 & 55 \\
\hline & Fast and powerful & 85 & 23.6 \\
\hline & Monitoring events & 77 & 21.38 \\
\hline
\end{tabular}

From the above table it is clear that in $55 \%$ of cases, the police response is weak or slow in relation to the speed of events. This may be attributed, according to the participants' opinion, to the distance of the police stations from the sites of the events, or to the weakness of the police in terms of means of movement and the severity of the routes at the sites of events.

Appropriate and immediate responses were confirmed by $23.6 \%$ of respondents, which are effective in calming events.

However, $21.38 \%$ of respondents said that police sometimes monitor events and do not intervene, for reasons they do not know, and this leads to an escalation of events and forcing people to retaliate.

There is an urgent need to answer the strategic question below, which is crucial in the traditional tribal wars 
in Darfur:

Who is fueling the war and supervising the perpetuation of the conflict?

\begin{tabular}{|l|l|l|l|}
\hline$\#$ & Who is fueling the war & $\#$ of Answers & $\%$ \\
\hline 1 & Hakama & 110 & 30.55 \\
\hline 2 & Elaqeed & 78 & 21.66 \\
\hline 3 & Intellectuals and politicians & 46 & 12.77 \\
\hline 4 & Weapon proliferation & 40 & 11.11 \\
\hline 5 & Absence of state power & 31 & 8.61 \\
\hline 6 & The negative role of the youth and knights of the tribe & 25 & 6.94 \\
\hline 7 & Traditional civil administration agenda & 30 & 8.33 \\
\hline
\end{tabular}

The previous table shows that the Hakama play the main role in fueling the flames of war by $30.55 \%$, and $21.66 \%$ of the factors fueling the conflict in the hands of Elaqeed and comes in third place with $12.77 \%$ of educated tribesmen. Weapons in the hands of citizens constitute $11.11 \%$ of the factors, while the absence of state power represents $8.61 \%$ in the opinion of the participants and comes in sixth place with $8.33 \%$ the role of the traditional civil administration, and finally, the share of youth and tribal knights is $6.94 \%$.

Through the respondents' answers, we find that there are key elements that fuel the conflicts and their durability, which may not exceed hours at times, and may extend for several days, depending on the size of the warring tribes, their weight and their preparations for war in terms of arming and cavalry. It is important to clarify these elements in some detail:

\section{Hakama:}

The Darfurian proverb says that, (women weight the work of men), according to tribal customs and traditions.

Hakama. ${ }^{(1)}$ is the woman who composes poetry in the tribe. Inspiring enthusiasm of the knights, says poetry and singing to illustrate the greatness of the tribe, its origin and glories and pride, courage of its knights, urges them to do good things and help the weak people in the tribe.

It is known that Hakama constitute a powerful, influential and dangerous group of tribal women, with moral authority among the tribes in most parts of Sudan in general, and in Darfur in particular.

Recently, however, this institution has deviated from the positive role it plays and has become an important element in spreading a culture of tribal violence, revenge and the drums of war. The Knights of the tribe work to achieve the satisfaction of this institution, by working according to the achievement of its agenda, at all costs.

\section{Elaqeed:}

Elaqeed in the tribe holds the banner of collective action. Like the role of Hakama, the role of Elaqeed in the tribe is to lead the tribal organization in hunting and confronting wild animals, as well as to organize and lead the agriculture, construction, and voluntary and charitable collective work within the tribe. However, in the recent period, Elaqeed turned to be responsible for the war operations in the tribe, they serve as the staff of the tribe war, and its war council, and determine how to deal with events, Such as revenge, respond to enemy attacks and determine the zero hour, location and response size. No one can violate their orders, or go in the opposite direction, because they are the tongue of the tribe and its commander obeyed during the war.

\section{Intellectuals and politicians:}

As noted in the context of this paper, illiteracy constitutes a high percentage of the population of Darfur, and the tribe intellectuals are the owners of opinion and advice in the affairs of the tribe, as people of knowledge, and ordinary citizens believe that their opinion is right with regard to the tribe and its status and future, they are the pride of the tribe, but Unfortunately, they were not freed from the negative in their culture, and did not play any role among their tribes to spread the culture of peace, love and peaceful coexistence, and we find them always, as indicated by the participants in the questionnaire, philosophize and interpret events other than reality, trying to give dimensions irrelevant to reality, which establishes a culture of violence and War, and then come after that politicians detailing the political cover of a problem which increases fire inflamed.

The above does not deny that there are intellectuals from the region playing a positive role in changing the bad perceptions in the culture of the tribe, but they exercise this role away from the tribe community, in Khartoum, the capital, or outside Sudan, and through the media in the radio, television, local and international newspapers. They take part in seminars and events, but this is far from the target groups, and even the few who reach these messages, reach them in an incomprehensible language for the simple person, who is the fuel of these conflicts, and thus this group of educated Darfurian remains confined to a very limited range, In a social and cultural environment far from the target.

19. A. Al-Jedi, Hakama Sing, Baramkeh Poetry, Baramkeh Group for Folklore, Center for Peace Studies, University of Nyala, January 2006. 


\section{Traditional civil administration:}

Although the traditional civil administration plays a positive role in resolving disputes and concluding intertribal peace agreements, it is sometimes one of the factors that fuel the conflict, in terms of its bias towards one of the parties to the conflict, arbitrary sentencing and sanctions against the disputed, as well as disputes to control As the mayor, the expansion of influence and other what is known in such communities.

The lack of communication between modern state institutions and traditional institutions created a huge gap between tribesmen and these institutions.

The deprivation of the traditional civil administration from all its powers under the rule of President Nimeiri, and wasting the opportunity to attach it to the general framework of the institutions of the modern state, to cope with the requirements of social change, this led to a great rift in the loyalty of the citizen in Darfur, in what looks like a schizophrenia between belonging to the institutions of the modern state, or, Traditional civil administration.

\section{Absence of government institutions:}

All those who participated in the questionnaire agreed that the government recorded a significant and noticeable absence from the scene of the events in Darfur, and its intervention always comes too late, slowly and inconclusively, after the conflict erupted, spreading and splitting its parties, which is difficult to address, and in the absence of the prestige of the state and the law. Chaos and the law of the jungle become masters of the situation, prompting people to take the law into their own hands, and then to exchange revenge, fuel the conflict, prolonged and losses.

The availability of weapons in hands of citizens:

The proliferation of weapons of various kinds, cheap prices, easy access to them, and carry them publicly in the hands of citizens. The heavily armed human scene has become a common sight in Darfur, and the chaos in the possession of weapons by citizens makes it difficult to control its uses. It is a reason to commit crimes of armed looting, resisting army and police forces, killing unarmed citizens.

All these causes us to wonder how the conflict can be stopped?

\begin{tabular}{|l|l|l|l|}
\hline$\#$ & How to Stop Conflict & \# of answers & $\%$ \\
\hline 1 & Government intervention & 195 & 54.16 \\
\hline 2 & neighboring tribes intervention & 75 & 20.83 \\
\hline 3 & Traditional civil administration intervention & 45 & 12.5 \\
\hline 4 & Joint intervention by government and traditional civil administration & 45 & 12.5 \\
\hline
\end{tabular}

From the above table, it is clear that $.5416 \%$ of the conflicts end when the state intervenes and imposes its power after the conflict has escalated, and it is clear that it is a high percentage compared to other mechanisms contribute to the resolution of conflicts in the region.

If we add the joint intervention between the government and the civil administration, the percentage rises further to $66.66 \%$. In fact, this percentage does not diminish the effectiveness of the popular effort represented in the neighboring tribes from inside and outside Darfur, which constitutes $20.83 \%$, but also, we can say, that the intervention of the government and imposing its power, directly, or with the participation of the civil administration, is the most powerful tools of conflict resolution.

In addition to the aforementioned means, Judea is the main means of resolving conflicts in Darfur

\section{Judea: $\mathbf{l}^{(1)}$}

The Judea system is one of the oldest customary reconciliation mechanisms known to the inhabitants of Darfur. Therefore, this system is used from the lowest levels of the social system - the family - to the highest levels - the tribe - .

Judea works in the field of problem-solving on all types of social, economic, and political conflicts. For example, the Judea system works even in disputes over marriage and family matters as a means of finding solutions.

The culture and traditional character of these societies are often deterred from resorting to judicial courts to adjudicate disputes and prefer Judea.

The term "Judea" means a selected group of people mediates between adversaries or disputers in order to reach solutions that are acceptable to all parties.in other words, it means local leaders will consider solutions to problems or conflicts that arise between tribes in these communities.

It is used to resolve conflicts in all areas of Sudan, especially Darfur because of the complexity of tribal conflicts in the region and ethnic conflicts as well.

The concept of Judea is prevalent among the traditional tribal communities in Sudan.

20. Z. Saifuddin, Judaism in Darfur, Paper presented to the Workshop for Peaceful Coexistence, Relief and Reconstruction Commission, Ta'ayshi Hall, Nyala, South Darfur, February 2008 
The Judea Council consists of the leadership of the tribe, and the elderly who understand the customary laws and traditions of the tribe. If the conflict moves from within the tribe to the outside, and the parties to the conflict become two or more, then the council will consists of the leaders of those tribes.

The mediator in Judea must be neutral, flexible, and familiar with custom and the history of conflicts in the region.

The following table shows the best means in the opinion of the participants in the questionnaire to end conflicts and reach a sustainable reconciliation between the tribes.

\begin{tabular}{|c|c|c|c|}
\hline \# & The means & $\begin{array}{l}\text { \#of } \\
\text { Answers }\end{array}$ & $\%$ \\
\hline 1 & Deyat & 140 & .3888 \\
\hline 2 & Rawakeep & 95 & 26.38 \\
\hline 3 & $\begin{array}{l}\text { Giving powers to the traditional civil administration, defining nomadic routes and } \\
\text { paying attention to community development }\end{array}$ & 55 & 15.27 \\
\hline 4 & Karamat & 43 & 11.94 \\
\hline 5 & Government Compensation & 25 & 7.5 \\
\hline
\end{tabular}

The above answers show that a large number of respondents prefer traditional forms of conflict resolution, mechanisms and forms derived from Islamic religion, tribal heritage and local customs, as well as from their practical experience. Failure to pay blood money (Deyat) leads to a re-conflict, while $26.38 \%$ believe that tribal compensation (Rawakeep) . (1), an agreement between two tribes on specific compensation in the event of a conflict, has resulted in loss of property and lives, and commitment to it is important in Prevent the development of conflict.

In third place (15.27\%), the revitalization and development of traditional civil administration, the granting of powers, the identification of nomadic routes, as well as the prevention of indiscriminate agricultural expansion, at the expense of pastures, and attention to community development can lead to stability in the region.

Others $(11.94 \%)$ believe that (Karamat) can lead to calm and prevent the aggravation of the conflict, (Karamat), an amount of money estimated and agreed upon by senior tribesmen after the pardons of the murdered relatives for the murderer and gave up blood money, this is considered as a Compensation for the families of the dead, as an expression of goodwill and full reconciliation, while $7.5 \%$ believe that government compensation can be a method of conflict resolution.

\section{Analysis, indicators, and discussion:}

Statistical processing of the questionnaire and analysis of respondents' answers, focusing on strengths, weaknesses, opportunities and threats, in the tribal conflicts in Darfur. We think that, the use of the SWOT ANALYSIS model, through which we can come up with an interpretation of answers leads to contribute to a theoretical and practical framework make an additional contribution to explore the roots of the problem of tribal conflicts in Darfur and other similar areas, in order to contribute to a sustainable solution.

\section{Below is a review of these indicators:}

Indicator 1: Strengths in the pores of Darfurian society. Indicator 2: Weaknesses from the conflict environment. Indicator 3: Opportunities developed to reach stability. Indicator 4: Threats to overcome.

\section{Indicator 1: Strengths:}

1. When a state intervenes to resolve a conflict, there is always a positive response from the citizen to state power.

2. Heritage and custom is rich in experiences of resolving disputes that find a response in the courts, such as Rawakeeb, Judea, and Karamat as well as Deyat, which can be a good asset that contributes to the stability of the region.

3. In most conflicts, the first thing people think about is informing the authorities, the police or the traditional civil administration, so that, the law takes its course, which means the law is approved.

4. All events may be trapped in its initial phase, if state power exists, and there is an immediate response from the authorities concerned, at the time of the event, thus maintaining inter-tribal peace.

5. Citizen condemnation of juveniles, rejection of violence in conflict resolution, and the desire for stability and peaceful living among tribes.

21. A.Y. Atta, The Role of Darfurian Heritage in Promoting Culture of Peace, Darfur Crisis at the Crossroads, Paper presented to the Darfur Peace Workshop, Center for Peace Studies in cooperation with the American Peace Center, University of Nyala, South Darfur, 2007. 
6. All tribes in Darfur believe in Islam, which could be a unifying factor of vision and understanding, and facilitate the resolution of differences between tribes.

\section{Indicator 2: Weaknesses.}

1- The absence of state power, the divergence of police and army stations, the weakness of the capabilities, equipment and mechanisms of movement of the police and their slow intervention, the ruggedness of roads and mountain roads in the area.

2- Tribal nervousness

3- Overlap of tribal paths in pastures, agricultural expansion at the expense of pastures, and shrinking of natural pastures due to changing climatic conditions and desert encroachment.

4- Weakness of traditional civil administration, including its traditional authorities. The traditional civil administration sometimes biases tribes against another in some cases. In addition to the provisions of arbitrary fines imposed on the pastoralists for the benefit of farmers.

5- The negative role of some tribal intellectuals, among ordinary citizens, in fostering a culture of violence, rather than spreading a culture of peace among tribes.

6- The destructive and influential role of Hakama and Elaqeed among the tribes.

7- The proliferation of weapons, which are available to the citizen and affordable.

8- The spread of illiteracy and the socio-economic and political backwardness of the region.

\section{Indicator 3: Opportunities.}

1- Consensus to reject and condemn the fighting and wars, and the pursuit of reconciliation and the adoption of the principle of peaceful coexistence among citizens by all.

2- Consider tribal leaders as role models and ease of submission to them, as well as acceptance of customs and tribal heritage in solving problems.

3- Submission to State authority, when government intervenes in conflict resolution.

4- The firm conviction of the rule of law as the first reaction to any event.

5- Take advantage of the Islamic religion through mosques and religious schools to spread the culture of peace.

\section{Indicator 4: Threats.}

1- Prejudice and preference of one tribe over another when arbitrating conflicts.

2- The continued existence of unlicensed weapons in the hands of citizens.

3- Abolish traditional civil administration and impose modern civil state institutions without objective scientific studies and careful application.

\section{Seasons of armed tribal conflict:}

There are periods of high rate of armed conflict, which vary throughout the year.

In summer, it is the most productive season for conflict, as competition for water and pasture precipitates tribal conflicts, where pasture and water are insufficient for livestock. The conflicts in this season constitute $32.8 \%$ of the total conflicts.

Entering pastoralists' livestock on farms at the time of harvest provides a fertile environment for friction and conflict. This constitutes $22 \%$ of all conflicts.

In the autumn, farm abuse is a major cause of conflict, as well as friction between pastoralists on grazing paths and areas of stability during the fall. This constitutes $30.7 \%$.

There are other periods when conflicts erupt for reasons unrelated to the seasons: competition for local and national elections, conflicts originating from tribal revenge, and encroachment on tribal borders. This constitutes $14.5 \%$ of the conflicts discussed.

seasons of tribal conflict in Darfur

\begin{tabular}{|l|l|l|l|l|}
\hline Seasons & summer & Harvest & autumn & Others \\
\hline$\%$ & 32.8 & 22 & 30.7 & 14.5 \\
\hline
\end{tabular}




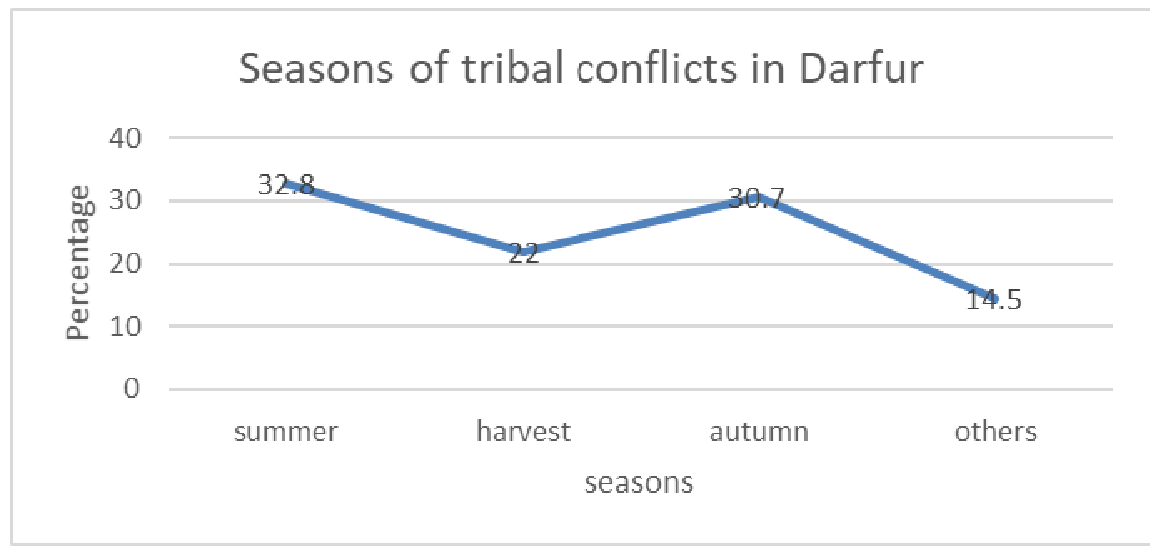

\section{Life cycle of tribal conflict:}

Based on the above, it can be said that the tribal armed conflict, is old as the tribe in Darfur. It has always been possible as a result of the region's economic and social underdevelopment, under extremely complex tribal institutions in their interrelationships and social laws.

The outcome of our discussion of the results of the analysis in a comprehensive manner, coupled with the seasons of the high frequency of conflict, all of this can be concluded in devising a life cycle of tribal conflicts in Darfur and come up with three phases of conflict as follows:

\section{Phase 1: Enrichment and formation of the conflict:}

The stage of enrichment and formation of the conflict, the stage in which the conflict, has not come out of the possible, into existence. This stage is formed according to objective conditions, the most important of which are: 1. The continuing decline in natural resources and the intensification of competition for natural resources as a result of:

- Drought and desert encroachment.

- Agricultural expansion at the expense of pastures.

- Overgrazing.

- Deterioration of forest cover due to lack of attention to environmental protection, which led to lack of rain.

- Loss of soil fertility due to soil dredging led to poor productivity.

2. Lack of interest in community development led to:

- Lack of productive investment projects that contribute to addressing the problem of unemployment, increase income, raise the standard of living and compacting poverty.

- Lack of infrastructure, roads, communications, etc.

- Extreme weakness in health and education services and the high prevalence of illiteracy and educational losses.

- Overlap in the paths of pastoralists and their livestock and the occupation of tribal areas by nomads.

- Weakness of the security institutions, including the police and armed forces.

- Weakness of the modern civil state institutions in the region.

3. The proliferation of unlicensed weapons, namely firearms and conventional weapons, among the population. Some features of this phase can be summarized in:

- Harassment, tribal intolerance, assuming the inferiority of the other and lack of mutual acceptance.

- Looting, theft and mutual accusations.

- Political competition, the pursuit of administrative independence and competition for land ownership.

There are perceptions that can prevent conflict from moving forward:

- Creating programs for community development, providing security and imposing state power.

- Planning and protecting nomadic routes.

- Maintenance and development of the pasture.

- Vertical expansion programs in agriculture rather than horizontal expansion.

- Environmental protection programs.

- Developing traditional civil administration and attaching it to state institutions.

- Planning and determining ownership of land and tribal areas.

This stage is where the conflict is asleep, or in a dormant state, and without achieving the conditions mentioned above, this can lead to an advanced stage in which the conflict comes into existence, through its violent expression, the stage of conflict eruption and escalation. This leads us directly to the next phase of the 
conflict.

\section{Phase II: Conflict Explosion:}

This phase of conflict is formed as a result of the action and reaction, usually by assaulting a tribal group against a group of different tribe, or a person of one tribe against a person of another different tribe, which are very sufficient reasons to enter into an armed tribal conflict. Armed conflict can be avoided if the following treatments are tried:

1. Rapid intervention by the State and its security and judicial organs to arrest and prosecute perpetrators in accordance with the law or tribal custom.

2. Developing and strengthening the traditional civil administration and giving it the appropriate authorities.

3. Installing permanent stations for police and security forces and imposing State power.

In the opposite cases of the remedies mentioned, the conflict moves to a more advanced stage.

\section{Phase 111: Conflict eruption and the difficulty of control:}

This is the stage of conflict and the difficulty of controlling, and if the second stage of the conflict has a short period of time, it may not exceed hours, then in the third stage, the period of conflict may last for days or weeks, and is characterized by the large amount of loss of life, in addition to material losses. The formation of painful and bitter memories, which are hostile and retaliatory among adversaries, all contribute to the intensification of the conflict, as now. Here is the intervention of the political agenda, and various interventions and ethnicity, which are often supervised and organized by intellectuals and politicians. Also at this stage, after 2002, the Darfur armed political movements began to emerge and organize under political and revolutionary cover, accompanied by a program and developmental political demand.

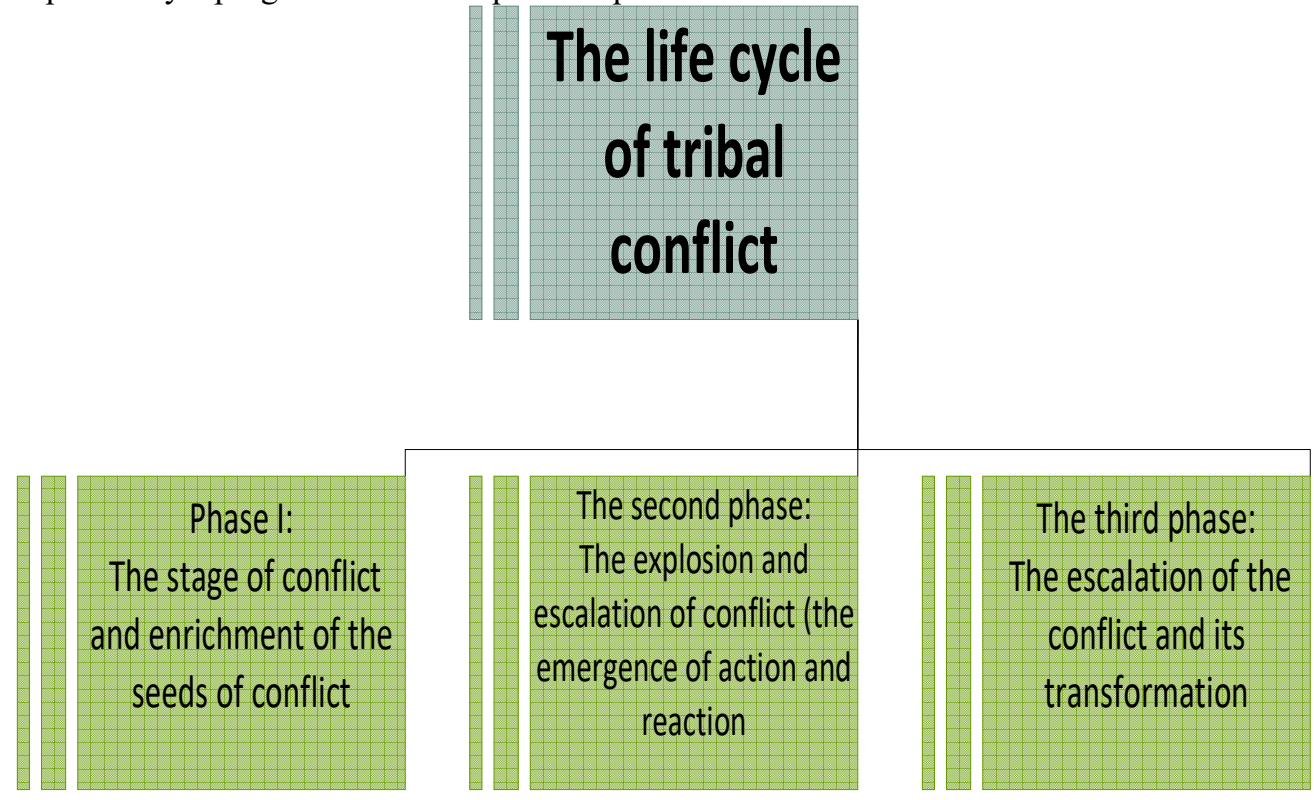




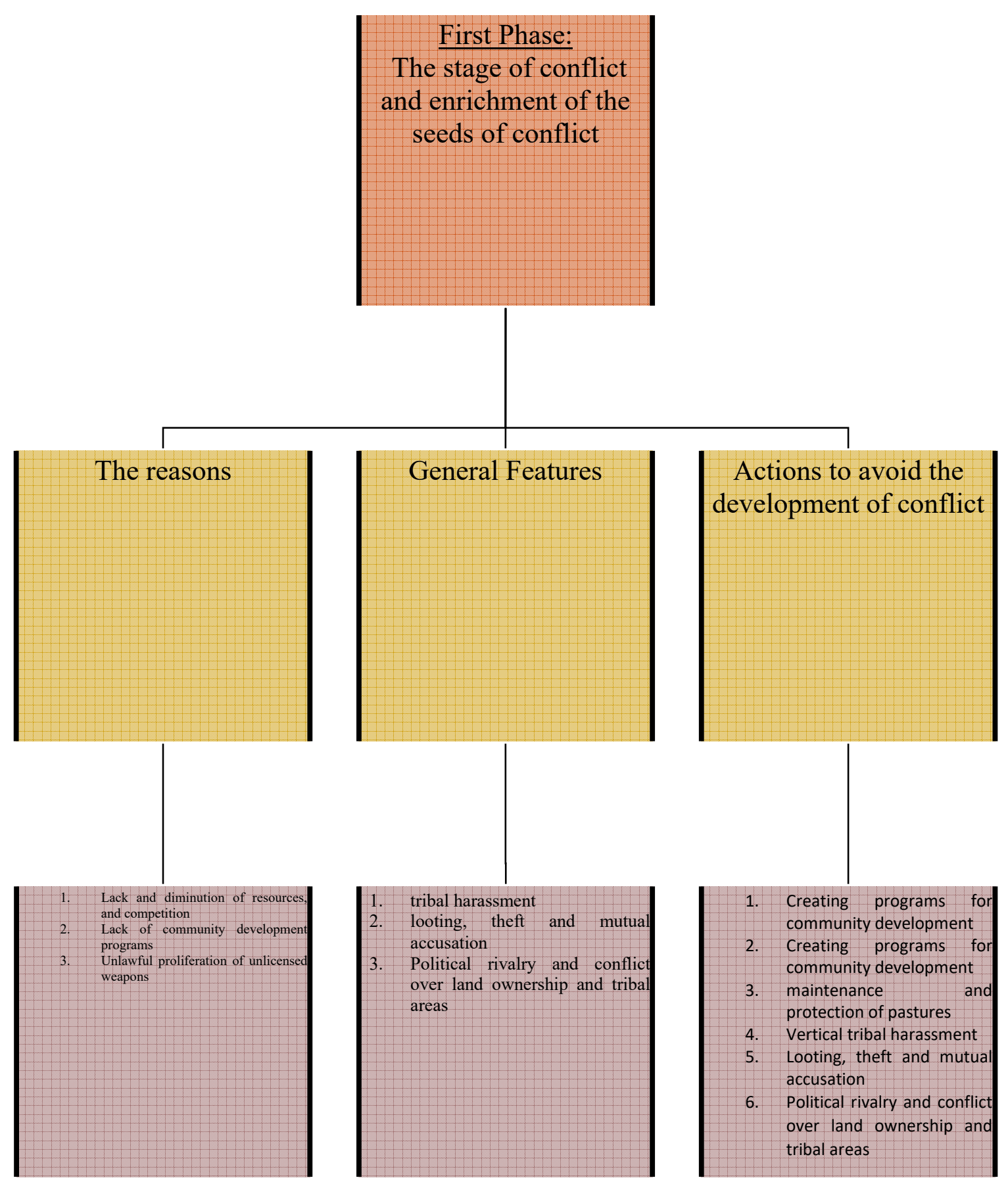

Absence of the conditions necessary to end the conflict at this stage 


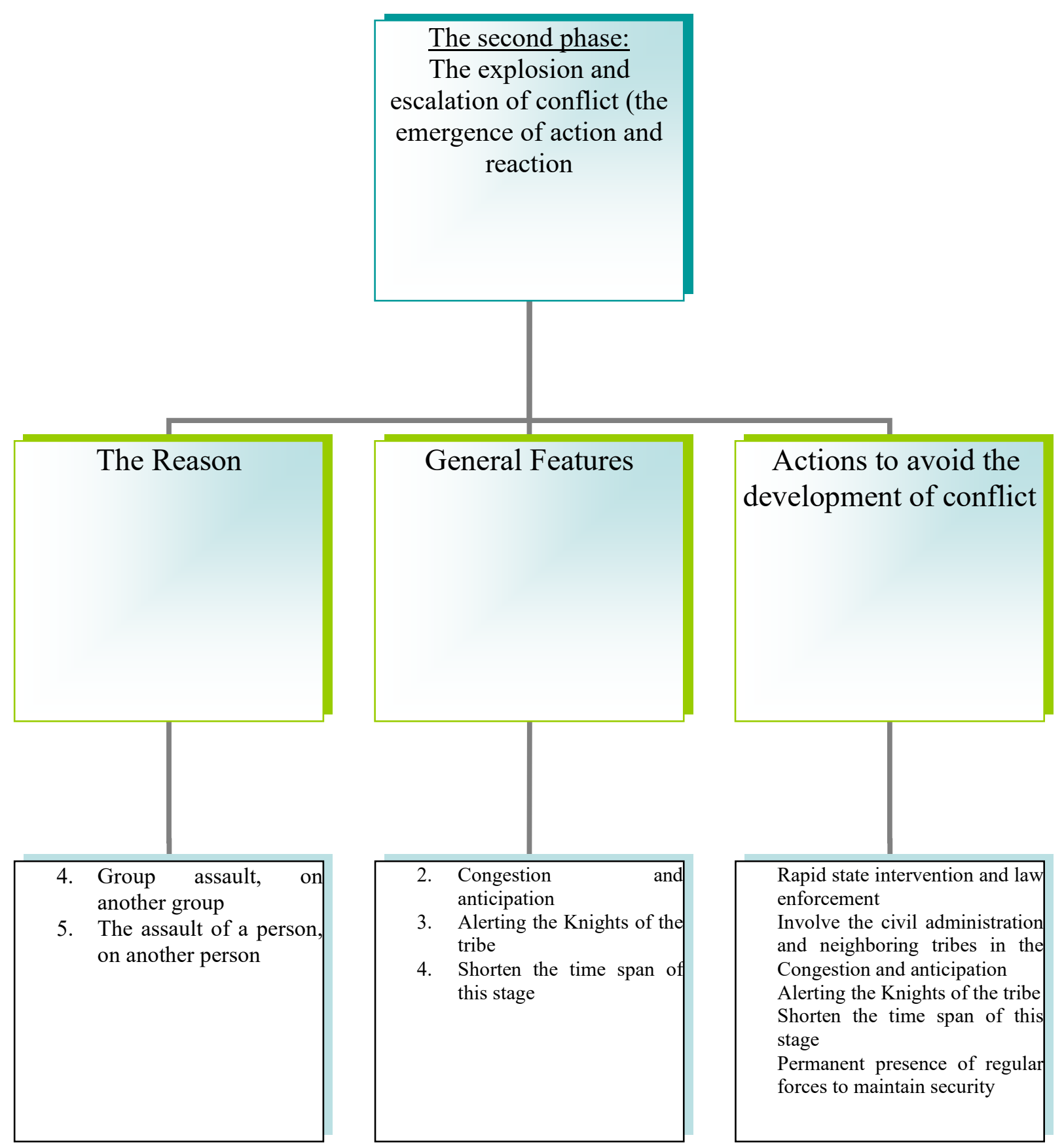

\section{Absence of the conditions necessary to end the conflict at this stage}




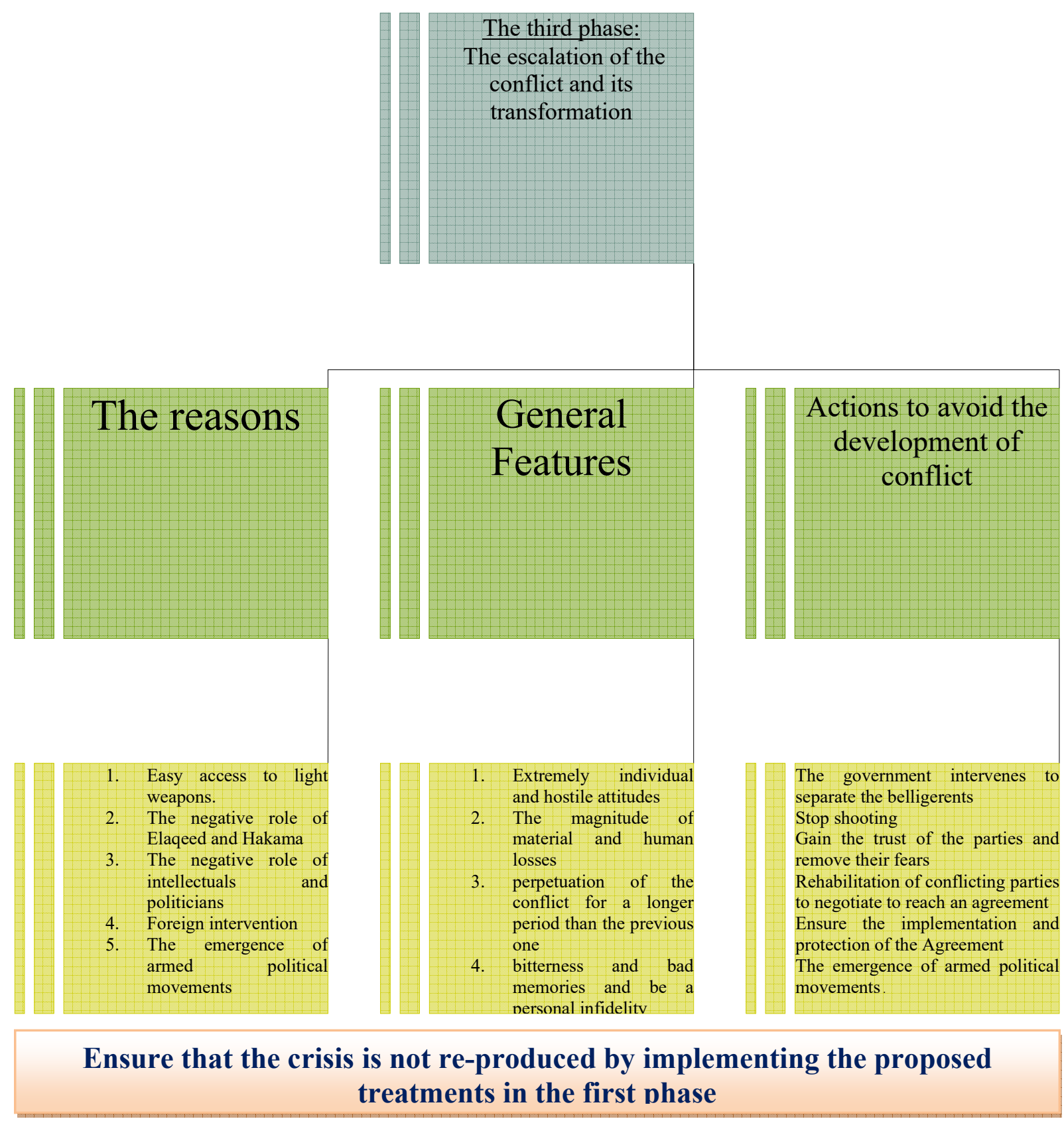

\section{Summary \& Conclusion:}

According to the questionnaire and, the treatment and analysis of the statistical tables in this paper, we can conclude that important insights can be considered as entry points for further research contributions and studies that open the way for qualitative shifts in Darfur's social and economic future, away from tribalism, war and chaos to the threshold of civilization and modernization:

1. the situation has not been beyond the scope of local, within the framework of traditional tribal conflicts, nor has it spiraled out of control, as evidenced by the state's intervention alone, or in solidarity with the civil administration, the conflict has always been resolved and contributes to the restoration of stability and control of the situation. Therefore, we believe that the imposition of the state's prestige and the strong and permanent presence of the police and security forces is a very important factor in ending the tribal conflicts in the bud, that is, the keys to a solution are in the hands of the government.

2. The area is dominated by the authority of the tribe institution and traditional civil administration, which are difficult to overcome, but can be developed to keep pace with the state of modern civil society.

3. The people of the region in general are not outlawed, not rebel against the authority of the central government, but they are under many pressures, from the cruelty of nature to economic, social and political backwardness. 
4. The spread of illiteracy in all its forms of alphabetical, economic, social and environmental, especially among women, leading to the birth of generations underdeveloped and unable to keep pace with development so that it reproduces the crisis.

5. The deprivation of traditional civil administration has led to considerable confusion and conflict in the loyalty of the citizen between the traditional civil administration and the institutions of the modern state. Traditional civil administration and tribal leadership occupy a place in the hearts of local citizens, so it was possible not to dissolve the civil administration by a decision, but it was better to develop and integrate in stages in the institutions of the modern state until the citizen is convinced of the effectiveness of the new administrative structures.

6. The region is rich in abundant and promising natural resources, which qualifies it to lead a major industrial revolution in the field of food processing in the region of Jebel Marra. There is a huge and well-known component of livestock and forests, as well as copper ore, iron, lead and other minerals. All these resources, if exploited well, followed by the construction of the required infrastructure and services, can change the situation of the region and its people by turning towards a modern civil society.

\section{References}

1. 2008 Census, Urban and Rural Population Distribution in South Darfur, Central Bureau of Statistics, Khartoum, Sudan, 2008.

2. Al-Jedi, Hakama Sing, Baramkeh Poetry, Baramkeh Group for Folklore, Center for Peace Studies, University of Nyala, January 2006.

3. A.Yusuf, the Mechanism of Tribal Armed Conflict in South Darfur, Sudanese Writings Journal, Issue 31, March 2005.

4. A.Y. Atta, The Role of Darfurian Heritage in Promoting Culture of Peace, Darfur Crisis at the Crossroads, Paper presented to the Darfur Peace Workshop, Center for Peace Studies in cooperation with the American Peace Center, University of Nyala, South Darfur, 2007.

5. Al-Tayeb Abdul Rahman Mukhtar, Causes of Tribal Conflicts in Darfur, Workshop entitled: Visions on Tribal Conflicts in Sudan, Al-Sharqa Hall, Khartoum University, 1998.

6. Al-Tijani Mustafa, the Tribal Conflict in Darfur, its Causes, Implications, and Treatment; A Study in Sociology and Applied Anthropology; Issued by Sudan Printing Press Co., Ltd., Khartoum, 1999.

7. Aoun Al-Sharif Gasim, Encyclopedia of Tribes and Genealogy in Sudan - First Edition, Afrography Press for Printing and Packaging, Khartoum, 1996.

8. Dr. Al - Tijani Mustafa Mohamed Saleh: Causes of Tribal Conflict in Sudan, paper presented at a seminar entitled (Visions on Tribal Conflicts in Sudan), Institute of African and Asian Studies, University of Khartoum, 1998.

9. Fouad Ali, Tribal Conflicts: Causes and Mechanisms for Resolving, Research Paper, Conflict Resolution Workshop, Africa International University, Khartoum, November 1996.

10. Haider Ibrahim Ali, Darfur Crisis: Causes and Future, Article, al-bait Al-Arabi Forum Conference, al-bait Al-Arabi Magazine, Madrid, September 2007

11. http://raseef22.com/article/1073721/june29,2017/Islam Abdulrahman/ the causes and consequences of the tribal conflict in Darfur

12. Juma Kinda, Marginalized Areas and the Political Future of Sudan, Sudanese Writings Journal, No. 3, Center for Sudanese Studies, Khartoum, 2005.

13. M. Al - Sharif: Ownership of Land and Al - Hawakir in Darfur, Paper presented to the Peace building Workshop, Center for Western Sudan Studies, Nyala, 2005.

14. Osama Ali Zein El Abidine, Darfur: The Historical Background of the Crisis and the Reasons for Its Development, Research Paper, Center for Middle East and Africa Studies, Khartoum, November 2003

15. Population Census 2008, Sudan States, Central Bureau of Statistics, Khartoum, Sudan, 2008.

16. Report of the Agriculture Sector Committee: Investment Map, Ministry of Economy and Manpower, South Darfur State, 2003

17. Resources and Environment in Darfur, State Ministry of Agriculture and Livestock Publications, Pasture Department, Nyala, South Darfur State, 2006.

18. Saifuddin, Judaism in Darfur, Paper presented to the Workshop for Peaceful Coexistence, Relief and Reconstruction Commission, Ta'ayshi Hall, Nyala, South Darfur, February 2008

19. Salem Ababneh, Sudan's Darfur Tribes (Western Sudan), first edition, Al-Dauzen Printing Press, Jordan, 1995.

20. Sudan Strategic Report, Center for Strategic Studies, Khartoum, Sudan, 2002.

21. Tim Neiblok, The Conflict of Power and Wealth in Sudan, From Independence to the Uprising, Translated by Al-Fatih Al-Tijani, Muhammad Ali, Without Publishing House, 1990. 